\title{
BIOGAS ACQUISITION FROM SELECTED MIXTURES OF EXPIRED FOOD PRODUCTS
}

\author{
Joanna Kazimierowicz ${ }^{1}$ \\ 1 Department of Environmental Engineering Systems, Faculty of Civil and Environmental Engineering, Bialystok \\ University of Technology, Wiejska St. 45A, 15-351Białystok, Poland, e-mail: j.kazimierowicz@pb.edu.pl
}

Received: 2017.04.20

Accepted: 2017.05.31

Published: 2017.07.01

\begin{abstract}
Issues connected with expired food products are a significant, however underestimated, problem. Currently, expired food, disposed of by manufacturing industry plans, trade and gastronomy, comprises the biggest content of waste. In retail chains such products are withdrawn from sale and become waste, which should be managed properly. Expired food cannot be reintroduced to the market or sold at reduced price or on special offers. Possibilities to use fermentation may enable both utilization of expired food and biogas acquisition - a source of renewable energy. Therefore, fermentation plays three important roles. Firstly, it is a method of converting the energy from expired food into useful fuel, i.e. biogas which can be stored and transported. Secondly, this is a method aiming at recycling organic waste into stable soil improvers, liquid fertilizers and energy. And thirdly, it is a method of waste inertisation with the objective to decrease adverse influence on the environment. This article indicates possibilities to obtain biogas from three selected mixtures of expired food products.
\end{abstract}

Keywords: expired food products, biogas, renewable energy

\section{INTRODUCTION}

To ensure energy security and counteract climate change European Union conducts policy whose aim is to reduce energy demand by improving energy efficiency, reducing greenhouse gases, increasing the use of energy from renewable sources and energy sources diversification [Głodek and Trembacz 2011].

Anaerobic digestion is a commonly acknowledged method of organic waste matter management which has several measurable advantages to the environment [Dubas and Piątek 2011]. Fermentation is used in the production of biogas from a wide range of materials, including household and industrial effluents, industrial and agriculture waste, energy crops [Chłopek and Szczepański 2012, Ward et al. 2008, Gaj et al. 2010, gaj and Cybulska 2002]. To produce biogas materials which differ from traditionally applied natural fertilizers - manure and slurry, household waste and sewage sludge are more and more com- monly used [Eder and Schulz 2007, Kazimierowicz J. and Z. 2014].

Anaerobic digestion is a complex biochemical process occurring in anaerobic conditions. Organic matter is decomposed by bacteria into simple compounds, i.e. mainly methane and carbon dioxide. Up to $60 \%$ of organic matter is converted into biogas as a result of fermentation. Biogas consists mainly of methane $\left(\mathrm{CH}_{4}\right)-$ $55-70 \%, 32-37 \% \mathrm{CO}_{2}, 0.2-0.4 \% \mathrm{~N}_{2}$ and $6 \mathrm{~g} / 100$ $\mathrm{m}^{3} \mathrm{H}_{2} \mathrm{~S}$. The pace of decomposition depends mostly on the properties and mass of the material, temperature and process duration selected optimally [Oslaj et al. 2010, Ogejo and Li 2010, Matsui and Koike 2010, Kazimierowicz 2014]. Proper fermentation temperature depends on the activity of bacteria and amounts to $30-35^{\circ} \mathrm{C}$ for mezophiles and $50-60{ }^{\circ} \mathrm{C}$ for thermophiles [Buraczewski and Bartoszek 1999, Sikora et al. 2008, Kurek et al. 2008].

Biogas created during fermentation is used to produce electric energy as well as heat. 
Technological treatment processes result in the creation of bio-methane, i.e. purified biogas with parameters similar to natural gas [Fuksa et al. 2012, Ciuła 2009].

\section{MATERIAL AND METHODS}

According to the data from the biggest retail chains, the following groups of products are expired most often and in the biggest quantities,:

1. meat products: pork and beef;

2. dairy: milk, cottage cheese, yoghurt;

3. fruit and vegetables: apples, carrot, tomatoes.

Three mixtures with different content of particular components were fermented. Table 1 shows the weight shares.

In the laboratory conditions substrates were homogenised, mixed in different proportions, then disinfected in $70{ }^{\circ} \mathrm{C}$ for one hour and in such a form were used as a batch into fermentation chambers. Before and after fermentation process, the amount of dry matter content was defined as well as the amount of organic and mineral fraction, by marking dry residue, remains and losses after roasting.

A set of two separate containers was used to this research. They were made of $2 \mathrm{~mm}$ steel plate covered by a layer of anti-corrosive paint. The chambers are of cylindrical shape and in the lower part - a reversed cone. Each of the three containers has 10-litre capacity. A single chamber is constructed from the following elements: a substrate intake, a valve discharging supernatant water, a valve discharging created gas and a valve emptying the chamber. Control filling is conducted by an oblong speculum. Chambers are installed on a joint load-bearing structure which is a trapezium-shape table made from a roll formed shape. The model is controlled by a switchboard with a main switch key, engine switch key, three knob switch keys with thermostats and indicator diodes and three thermometers. Substrate mixing is conducted by a mixer - a construction mixer.

Table 1. Percentage share of expired food products

\begin{tabular}{|c|c|c|c|}
\hline \multirow{2}{*}{ Batch } & \multicolumn{3}{|c|}{ Share [\% of fresh content] } \\
\cline { 2 - 4 } & Meat & Dairy & $\begin{array}{c}\text { Fruit and } \\
\text { vegetables }\end{array}$ \\
\hline I & 33 & 33 & 33 \\
\hline II & 50 & 30 & 20 \\
\hline III & 40 & 10 & 50 \\
\hline
\end{tabular}

A $0.25 \mathrm{~kW}$ single-phase motor was used to drive the mixer. Right-side rotation of the mixer causes up and down movement of the batch, what enables sustaining homogeneous suspension in the chamber and the same temperature in the whole mass. The batch is indirectly heated by water jacket made of $2 \mathrm{~mm}$ steel plate. Total capacity of the jacket is 8 litres. Water heating is conducted by an electric heater of $2000 \mathrm{~W}$, controlled by C-24 thermoregulator, which is equipped with a probe taking temperature and placed inside the water jacket. The "batch" temperature is shown on electron thermometer whose sensor probe is placed inside the fermentation chamber [Magrel 2002]. The equipment is shown in Figure 1.

\section{RESULTS AND DISCUSSION}

The research enabling batch specification used in the experiment was conducted, what is shown in Table 2.

The amount of biogas was measured daily. Table 3 and Figure 2 show the total amount of produced biogas.

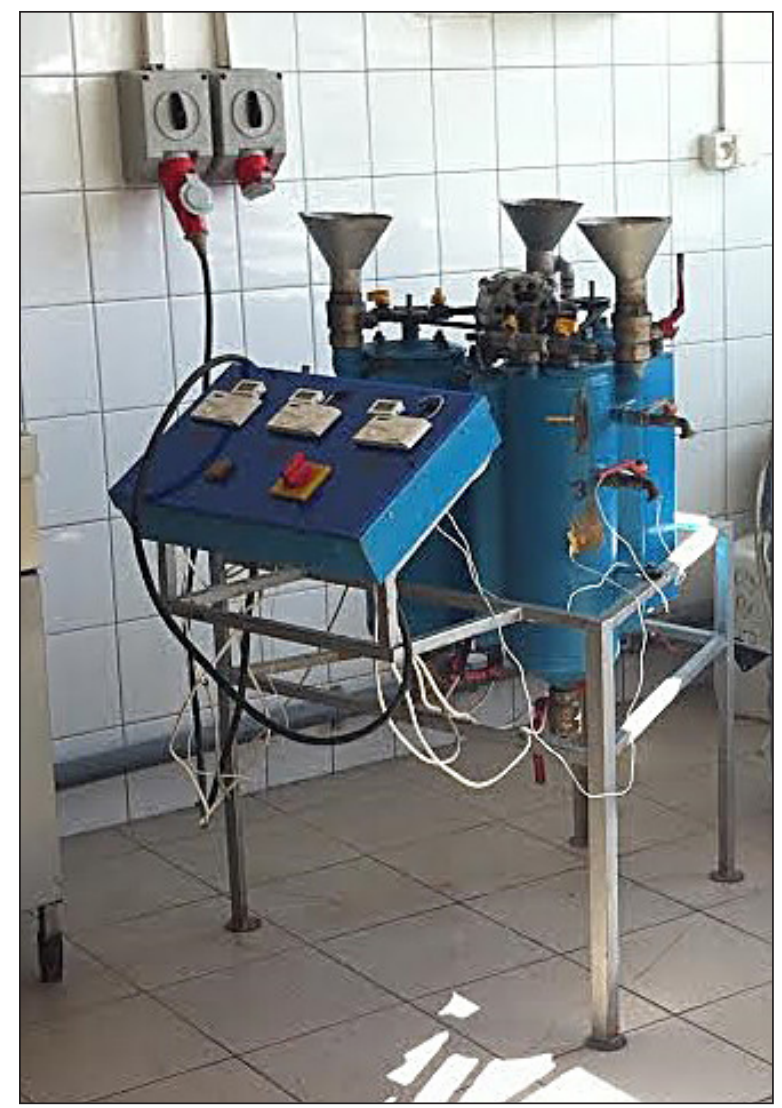

Figure 1. Reactors 
Table 2. Characteristics of the selected mixtures of expired food products before fermentation

\begin{tabular}{|c|c|c|c|c|}
\hline Batch & Dry matter [\%] & Water content [\%] & $\begin{array}{c}\text { Organic material content } \\
{[\% \text { s.m.] }}\end{array}$ & $\begin{array}{c}\text { Mineral material content } \\
{[\% \text { s.m.] }}\end{array}$ \\
\hline I & 21.4 & 78.6 & 78.4 & 21.6 \\
\hline II & 27.4 & 72.6 & 80.1 & 19.9 \\
\hline III & 22.2 & 77.8 & 81.9 & 18.1 \\
\hline
\end{tabular}

Table 3 The daily amount of produced biogas

\begin{tabular}{|c|c|c|c|}
\hline \multirow{2}{*}{ Days } & Batch I & Batch II & Batch III \\
\hline & $\mathrm{dm}^{3} / \mathrm{kg} \mathrm{s.m}$ & $\mathrm{dm}^{3} / \mathrm{kg} \mathrm{s.m.}$ & $\mathrm{dm}^{3} / \mathrm{kg} \mathrm{s.m}$ \\
\hline 1 & 73 & 84 & 82 \\
\hline 2 & 172 & 197 & 160 \\
\hline 3 & 231 & 264 & 314 \\
\hline 4 & 280 & 315 & 340 \\
\hline 5 & 311 & 352 & 371 \\
\hline 6 & 340 & 382 & 388 \\
\hline 7 & 357 & 401 & 401 \\
\hline 8 & 376 & 423 & 402 \\
\hline 9 & 403 & 458 & 403 \\
\hline 10 & 419 & 478 & 409 \\
\hline 11 & 435 & 499 & 415 \\
\hline 12 & 450 & 521 & 420 \\
\hline 13 & 461 & 536 & 423 \\
\hline 14 & 468 & 545 & 433 \\
\hline 15 & 472 & 549 & 440 \\
\hline 16 & 477 & 554 & 444 \\
\hline 17 & 479 & 557 & 447 \\
\hline 18 & 486 & 561 & 450 \\
\hline 19 & 488 & 567 & 455 \\
\hline 20 & 493 & 568 & 460 \\
\hline 21 & 495 & 568 & 466 \\
\hline 22 & 498 & 568 & 470 \\
\hline 23 & 503 & 568 & 474 \\
\hline 24 & 508 & 568 & 478 \\
\hline 25 & 513 & 568 & 482 \\
\hline 26 & 516 & 568 & 482 \\
\hline 27 & 519 & 568 & 482 \\
\hline 28 & 519 & 568 & 482 \\
\hline 29 & 519 & 568 & 482 \\
\hline 30 & 519 & 568 & 482 \\
\hline
\end{tabular}

The main product made during fermentation is biogas. The amount and chemical composition of biogas created during fermentation depends mainly on the chemical composition of the material used. The factor which determines the combustible value of biogas as a fuel is the content of methane. The bigger its share, the greater calorific value of the obtained biogas.

The biggest amounts of biogas, with the most significant content of methane (70-74\%) were obtained as a result of fermentation of methane mixture II. Methane share in biogas obtained from fermentation of mixture I and III amounted to $65-67 \%$ and $65-68 \%$ respectively. Thus an increased amount of meat fat negatively influences fermentation.

The amount of dry matter content and organic material in fermented batch was determined, what is shown in Table 4.

Regardless of the substrate used, similar specification of fermented material was obtained in anaerobic digestion. Dry matter was in a small range from $4.9 \%$ in option I of the experiment to $5.2 \%$ in option II. The highest concentration of organic material was found in option I and it amounted to $65.2 \%$, whereas the lowest was in option III, i.e. $64.1 \%$ of carbon compound. It should be stated that parameters describing fermented batch from the point of view of water and organic material content are very similar, regardless of the applied technological solution.

\section{CONCLUSIONS}

Research allow to state that the best technological effect was achieved in option II of the experiment, in which $50 \%$ constituted expired meat products, $30 \%$ dairy and only $20 \%$ fruit and vegetables. About $585 \mathrm{dm}^{3} / \mathrm{kg} \mathrm{s.m.} \mathrm{of} \mathrm{biogas} \mathrm{was}$ obtained, with the content of methane between 72 and $74 \%$. Methane fermentation of expired food products allows both utilization and acquisition of biogas - carrier of renewable energy. Proper share determination of products which are most often expired to the process of fermentation makes it optimal. Research is innovative and connected with organic waste disposal and current subject of renewable energy.

\section{Acknowledgements}

This article has been written within the work MB/WBiIŚ/5/2015 


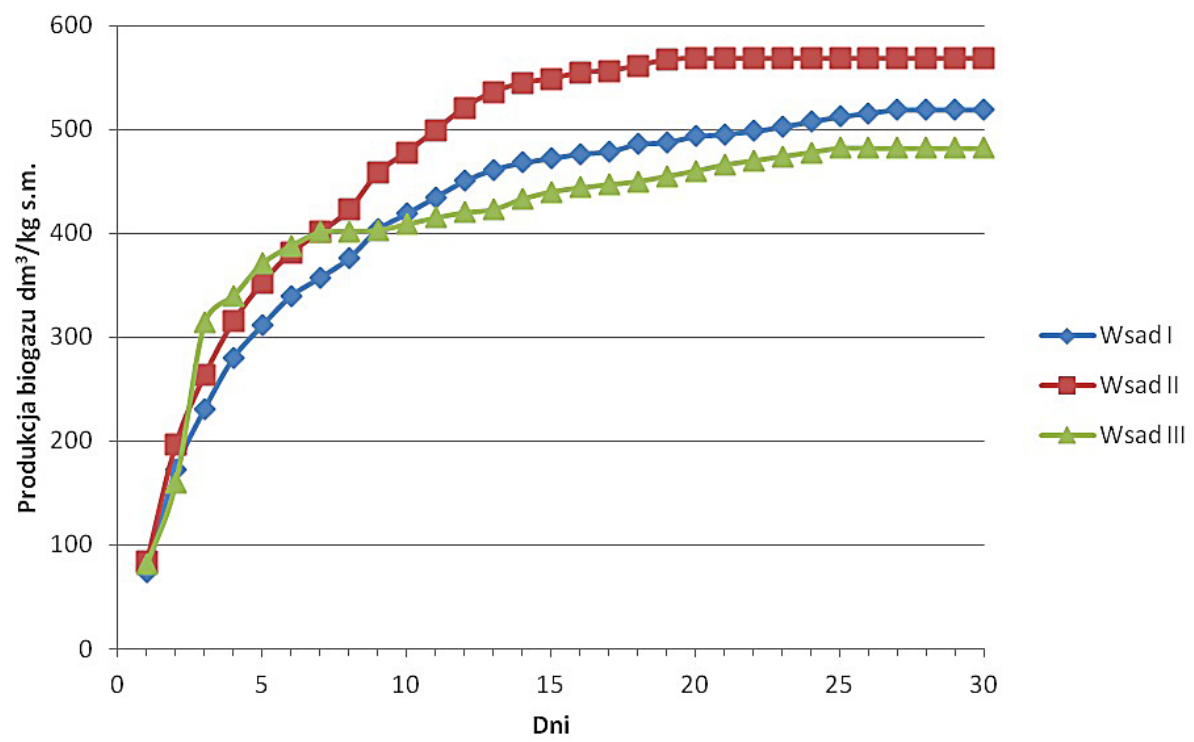

Figure 2. The total amount of produced biogas

Table 4. Characteristics of the selected mixtures of expired food products after fermentation

\begin{tabular}{|c|c|c|c|c|}
\hline Batch & Dry matter [\%] & Water content [\%] & $\begin{array}{c}\text { Organic material content } \\
{[\% \text { s.m.] }}\end{array}$ & $\begin{array}{c}\text { Mineral material content } \\
{[\% \text { s.m.] }}\end{array}$ \\
\hline I & 4.9 & 95.1 & 65.2 & 34.8 \\
\hline II & 5.2 & 94.8 & 64.2 & 35.8 \\
\hline III & 5.0 & 95.0 & 64.1 & 35.6 \\
\hline
\end{tabular}

\section{REFERENCES}

1. Buraczewski G., Bartoszek B. 1999. Biogaz: wytwarzanie i wykorzystanie. PWN, Warszawa.

2. Chłopek Z., Szczepański T. 2012. Zastosowanie paliwa biogazowego $\mathrm{w}$ transporcie publicznym $\mathrm{w}$ celu zmniejszenia zanieczyszczenia środowiska w strefach chronionych ekologicznie. Inżynieria Ekologiczna, 30: 27-35.

3. Ciuła J. 2009. Biogaz składowiskowy jako źródło energii odnawialnej. AURA Ochrona środowiska, nr 5, s. 23-25.

4. Dubas J. W., Piątek R. 2011. Identyfikacja przykładowego projektu biogazowego - wybrane aspekty techniczne i ekonomiczne. Koszalin. Wykorzystanie biomasy w energetyce - aspekty ekonomiczne i ekologiczne.

5. Eder B., Schulz H. 2007. Biogas Praxis. Okobuch Magnum. Freiburg.

6. Fuksa D., Ciszyńska E., Łyko P. 2012. Pozytywne aspekty wykorzystania biogazu na przykładzie transportu. Zakopane. Konferencja IZIP.

7. Gaj K., Cybulska H. 2002. Modelowanie emisji biogazu ze składowisk odpadów komunalnych. Chemia i Inżynieria Ekologiczna, nr 1, 91-100.

8. Gaj K., Knop F., Cybulska-Szulc H. 2010. Badania sezonowej zmienności składu bioga- zu powstającego procesie fermentacji osadów ściekowych Oczyszczanie ścieków i przeróbka osadów ściekowych. T. 4 / red. nauk. Zofia Sadecka. Zielona Góra : Ofic. Wyd. Uniwersytetu Zielonogórskiego, 113-123, Forum Eksploatatora 6/2010, 70-75.

9. Głodek E., Trembacz J. 2011. Efekty wykorzystania gazu uzyskanego ze zgazowania biomasy i odpadów do wypalania klinkieru. Warszawa-Opole. Prace Instytutu Ceramiki i Materiałów Budowlanych Nr 7, Rok IV, 97-107.

10. Kazimierowicz J. 2014. Organic waste used in agricultural biogas plants, Journal of Ecological Engineering, Vol. 15, nr 2, s. 88-92.

11. Kazimierowicz J., Kazimierowicz Z. 2014. Agricultural biogas plants : [rozdz.] / In: Environmental engineering - through a young eye [Dokument elektroniczny]. Vol. 9 / ed. Iwona Skoczko, Janina Piekutin, Aleksandra Kłębek. - Białystok : Oficyna Wydawnicza Politechniki Białostockiej, 115-143. - Summ.. - CD-ROM.

12. Kurek S., Małucha K., Toch R., Zemanek J. 2008. Wyznaczanie procentowego składu frakcji w odpadach komunalnych w zależności o systemu zbiórki Materiały konferencyjne: IV Ogólnopol-ska Młodzieżowa Konferencja Naukowa nt.: „Nowe tendencje rozwoju rolnictwa i obsza-rów wiejskich", s. 100-103. 
13. Magrel L. 2002. Metodyka oceny efektywności procesu fermentacji metanowej wybranych osadów ściekowych. Wydawnictwo Politechniki Białostockiej, Białystok.

14. Matsui T., Koike Y. 2010. Methane fermentation of a mixture of seaweed and milk at a pilot-scale plant. J. Biosci. Bioeng., 110(5): 558-563.

15. Ogejo J.A., Li L. 2010. Enhancing biomethane production from flush dairy manure with turkey processing wastewater. Applied Energy, 87: 3171-3177.

16. Oslaj M., Mursec B., Vindis P. 2010. Biogas pro- duction from maize hybrids. Biomass and Bioenergy. Vol. 34 s. 1538-1545..

17. Sikora J., Stawowski W., Wozniak A., Zemanek J. 2008. Określenie ilości biogazu z różnych odpadów organicznych pochodzenia komunalnego. Infrastruktura i Ekologia Terenów Wiejskich. $\mathrm{Nr}$ 8, Polska Akademia Nauk, Oddział w Krakowie, s.169-178.

18. Ward A.J.,Hobbs P.J., Holliman P.J., Jones D.L. 2008. Optimisation of the anaerobic digestion of agricultural resources. Bioresource Technology, 99:7928-7940. 